УДК 330.3:338.048-6:[347.724:634]

DOI: $10.15673 /$ fie.v11i1.1289

Лайко О.I.

доктор економічних наук, старший науковий співробітник

E-mail: alexlayko@gmail.com

ORCID ID: 0000-0001-7082-0862

Торган В.B.

аспірант

відділ міжрегіонального економічного розвитку Українського Причорномор`я Інститут проблем ринку та економіко-екологічних досліджень НАН України Французький бульвар, 29, м. Одеса, Україна, 65044

E-mail: torganvv@gmail.com

ORCID ID: 0000-0002-8619-6117

\title{
РОЛЬ САДІВНИЦЬКИХ ТОВАРИСТВ В ЗАБЕЗПЕЧЕННІ РОЗВИТКУ ГАСТРОНОМІЧНИХ АТРАКЦІЙ І ФОРМУВАННІ ТУРИСТИЧНИХ ДЕСТИНАЦІЙ НА ЗАСАДАХ ЗЕЛЕНОЇ ЕКОНОМІКИ
}

Садівництво, як і будь яка інша праця на землі $€$ не тільки пріоритетним сектором економіки, але і захоплюючим хобі, яке у поєднанні з самобутньою місцевою культурою та кухнею здатне створити унікальну туристичну пропозицію та привернути увагу значного кола внутрішніх та іноземних туристів. У статті розглядаються підходи та дається визначення сутності понять гастрономічний туризм та гастрономічна атракція, визначається класифікація гастрономічних атракцій, обґрунтовується роль садівницьких товариств у розбудові гастрономічних атракцій, як інструмента розвитку гастрономічного туризму в територіальних громадах України на засадах зеленої економіки. Метою статті є обґрунтування ролі садівницьких товариств в забезпеченні розвитку гастрономічних атракцій та сприянні формуванню туристичних дестинацій у сільській та приміській місцевості територіальних громад на засадах зеленої економіки. Обґрунтовано роль садівницьких товариств, як інструменту розвитку гастрономічних атракцій, формування туристичних дестинацій та забезпечення сталого розвитку територіальних громад на засадах зеленої економіки. Встановлено, що садівницькі товариства як основа гастрономічних атракцій є підґрунтям формування туристичних дестинацій у територіальних громадах, та у подальшому сприятимуть стимулюванню зростання економічної активності, посиленню процесів рурбанізації та забезпечуватимуть сталий розвиток туризму в територіальних громадах на засадах зеленої економіки. Концептуальні засади, механізми та інструменти управління садівничими товариствами в якості гастрономічних атракцій та туристичних дестинацій становлять предмет і перспективи для подальших наукових досліджень в даному напрямку.

Ключові слова: гастрономія, гастрономічний туризм, садівницькі (садівничі) товариства, гастрономічні атракції, туристичні дестинації, сталий розвиток територіальних громад, зелена економіка.

This work is licensed under a Creative Commons Attribution 4.0 International License http://creativecommons.org/licenses/by/4.0/

Постановка проблеми та її зв'язок з важливими науковими та практичними завданнями. В наслідок активної децентралізації реформовані та новоутворені територіальні громади потребують стабілізації соціально-економічного розвитку. Одним із ефективних напрямків, за допомогою якого можливо стабілізувати та стимулювати сталий розвиток територіальних громад, $\epsilon$ туризм. Для місцевих громад туризм - це не тільки різновид господарської діяльності, він є фактором об'єднання ресурсів та потенціалів 3 різних галузей господарства, що здатен активізувати розбудову територіальної громади у визначеному векторі.

Схвалена Кабінетом міністрів України Стратегія розвитку туризму та курортів на період до 2026 року визначила засади правових, економічних, фінан- сових та організаційних механізмів державного регулювання сфери туризму, складовою яких є цільові та регіональні програми розвитку сфери туризму та курортів [1]. Проведений аналіз свідчить, що більшість регіональних і місцевих програм розвитку туризму мають в якості завдання створення нових туристичних продуктів в тому числі в сфері гастрономічного туризму.

Відсутність в нормативно-правових актах чіткого визначення термінології гастрономічного туризму та наявність неоднозначності поглядів на сутність такої категорії в українській науковій літературі, призводять до складнощів у позиціюванні, звужує географію та зменшує розмаїття гастрономічних атракцій, що зменшує позитивні економічні та соціальні ефекти від туристичної діяльності для територіальних гро- 
мад. Разом з тим, з кожним роком потреби споживачів у отриманні нових вражень через гастрономічний туризм зростають і тому ця сфера туризму потребує розбудови, відкриття нових, налагодження та покращення діяльності існуючих туристичних атракцій, створення розгалужених гастрономічних мереж, що здатні забезпечити залучення різних груп населення територіальних громад до створення та споживання різноманітних якісних туристичних продуктів і одночасно сприятимуть формуванню туристичних дестинацій та стійкої основи для позиціювання територіальних громад з точки зору гастрономії у ракурсі привабливості для туристів.

Аналіз останніх публікацій по проблемі. Наукові дослідження сутності, особливостей формування, закономірностей розвитку гастрономічного туризму викладені у роботах зарубіжних та вітчизняних вчених: Агеєнко О.Г., Антоненко В.Г., Бабкіна О.В., Басюка Д.І., Божука Т.І., Бусигіна А.П., Ковешнікова В.C, Комарніцького І.О., Корнілової В.В., Кукліної Т.С., Расулової А.М., Саламатіної С.Є, Стельмаха О.А., Каурової А.Д., Коваленко К.Ю., Прокопчук Л.А., Федорченка В., Холл К., Мітчелл Р., Вольф Е., та інших.

Аналіз даних Державної служби статистики України за 2011 -2017 роки щодо розподілу кількості туристів за метою поїздки та видами туризму показав, що мотиваційна структура туристичних подорожей громадян України сприяє збільшенню попиту на міжнародні подорожі, тобто виїзний туризм: 1071637 туристів у 2011 році проти 1972028 у 2017 році; тоді як попит громадян на подорожі по Україні (внутрішній туризм) залишається майже незмінним: 369520 туристів у 2011 році проти 393396 у 2017 році. Дещо іншу картину демонструють статистичні дані щодо в’їного туризму: 109912 іноземних туристів у 2011 році проти 38563 туристів у 2017 році [2].

Така статистика свідчить, що національний туристичний ринок України на сьогоднішній день має низьку спроможність до спонукання інтересу туриста приймати участь в туристичних турах по країні, характеризується недостатньою кількістю привабливих туристичних дестинацій та туристичних атракцій. Існуючі туристичні продукти обмежені в різноманітті якісних туристичних послуг і не завжди здатні відповідати потребам іноземного і внутрішнього туриста.

Практично усі громади погоджуються, що розвиток туризму $є$ надзвичайно важливим для їхнього майбутнього. Однак, більшість навіть не уявляють, як саме можна його розвивати і тому значна кількість громад увесь розвиток туризму зводять лише до брендінгу існуючих об'єктів, які на думку місцевих влад можуть складати інтерес для туристів. Ані держава, ані приватний сектор не звертають уваги на могутній туристичний потенціал який є майже у кожній громаді - садівницькі товариства, які у поєднанні з можливостями гастрономічного туризму здатні стати точками тяжіння не тільки внутрішніх туристів, а й іноземців, що забезпечить розвиток гастрономічних атракцій, формування туристичних дестинацій та сприятиме розбудові територіальних громад на заса- дах зеленої економіки.

Формулювання цілей дослідження. В даному дослідженні планується розглянути сутність гастрономії як окремої складової сфери туризму, визначити сутність терміну гастрономічний туризм, дати визначення поняттю гастрономічна атракція та розглянити класифікацію видів гастрономічних атракцій, визначити роль садівницьких товариств, в якості інструменту розвитку гастрономічного туризму, що здатний забезпечити розвиток гастрономічних атракцій і формування туристичних дестинацій в територіальних громадах на засадах зеленої економіки.

Виклад основних результатів та їх обгрунтування. Останнє десятиріччя відзначилось якісними трансформаціями сфери туризму, відбувся перехід від визначення мети подорожі під терміном «харчовий туризм»/《food tourism» (UNWTO, Global Report on Food Tourism, 2012 рік) до більш спеціалізованого терміну «гастрономічний туризм»/«gastronomy tourism» (UNWTO, Second Global Report on Gastronomy Tourism, 2017 рік), що підтверджує - гастрономія перейшла із поняття «складова» у поняття «головна мета» туристичної подорожі та стала основою окремого сектор туризму - гастрономічного туризму.

Сучасна українська туризмологія термін «гастрономічний туризм» трактує за підходами як вітчизняних науковців так і представників міжнародних туристичних організацій. Наприклад, Всесвітня асоціація продовольчого туризму визначає гастрономічний туризм як подорожі з метою отримання аутентичного досвіду, заснованого на культурі споживання іжі або напоїв [7].

Д. Дасілва під зазначеним терміном розуміє «будь-який досвід туризму, в якому високо цінується i/або споживається їжа і напої, які відображають місцеву, регіональну або національну кухню, традиції, культуру, традиційні або кулінарні методи» [3].

На думку Д.І. Басюка, під терміном «гастрономічного туризму» треба розуміти вид туризму, що пов'язаний зі ознайомленням 3 виробництвом, технологією приготування та дегустацією національних страв та напоїв, а також кулінарними традиціями народів світу. Таке визначення дається автором як похідне від терміну гастрономія - науки, що вивчає зв'язок між харчуванням та культурою, що відноситься до галузі соціальних дисциплін [4].

С. Саламатіна дає таке визначення цього виду туризму: «гастрономічний туризм - вид діяльності, метою якої $є$ знайомство 3 етнічною кухнею країни або регіону, основними продуктами, особливостями технології приготування страв, а також підвищення рівня знань із кулінарії» [5].

Х. Ридван під терміном «гастрономічний туризм» розуміє туризм, який розроблений місцевими громадами для підтримання сільського господарства [6].

Засновник харчової індустрії туризму і виконавчий директор Всесвітньої асоціації продовольчого туризму Е. Вольф дає таке визначення: «Гастрономічний туризм - це пошук і насолода унікальною, неза- 
бутньою їжею і напоями як на іншому кінці Землі, так i на сусідній вулиці, адже, крім подорожей по своїй країні або всьому світі, ми також можемо стати гастрономічними туристами у своєму регіоні, місті чи навіть районі» [7]

М. Брокей трактує поняття «гастрономічний туризм» як «новий досвід, який шукають туристи, а саме - гастрономічний відпочинок, тури із садівництва та гастрономії» [8].

В українській науковій літературі до теперішнього часу не узгоджено єдиного визначення поняття «гастрономічний туризм», також не містить визначення цього терміну і нормативно-правова база, що негативно впливає на розвиток сфери туризму. Наслідком такої невизначеності є неправильне позиціювання та викривлення мети подорожей підчас гастрономічного туризму, що призводить до спотворення структури гастрономічного туру і створює умови для невірного сприйняття гастрономії туристами, а також звужує географію розповсюдження гастрономічного туризму в Україні, створює перепони із включення на карти туристичних подорожей нових туристичних гастрономічних об'єктів та маршрутів.

3 чого і де починається «Гастрономія»? Французький поет Жозеф де Бершу (Joseph de Berchoux), у 1801 році першим вжив слово «гастрономія» у назві поеми, своїм твором він сформував в суспільстві ставлення до суті цього терміну, як до вишуканого мистецтва трапези, що накопичує тільки найрідкісніше i витончене про їжу та смаки. Автор бачив у гастрономії втілення цінностей історії, культури, гуманності, уособлення історичних переваг цивілізації над варварством.

У сучасній науковій літературі існує декілька підходів до визначення суті цього терміну, під «гастрономією» розуміють: по-перше - розуміння і знання тонкощів кулінарного мистецтва; витончений смак в їжі [9]; по-друге - походить від грецького gaster - черево, i nomos закон - мистецтво готувати смачні і витончені страви [10]; по-третє - це сукупність правил, які визначають мистецтво вироблення хорошої їжі (Словник французької мови Е. Літрі 3 французької академії, 1873.); по-четверте - це практика чи мистецтво вибору, приготування та споживання кращої їжі; вивчення взаємозв'язку між їжею і культурою, мистецтво приготування і обслуговування дорогих і апетитних продуктів, стилі приготування в певних регіонах і науки про кращу їжу [11].

Грунтуючись на вищевикладеному можна зробити висновок, що сутністю гастрономії $є$ мистецтво, як форма творчої діяльності людини, форма культури відтворення за якої людина з особливими вміннями за допомогою спеціальних прийомів та методів створює витончені оригінальні готові до вживання високоякісні продукти харчування, страви та напої з унікальними смаковими властивостями. Саме тому, щоб виник гастрономічний продукт важливим є поєднання таких складових як якість харчових продуктів, точність в рецептурі, вміння володіти своєю справою майстерно і талант тонко відчувати смаки.

Проаналізувавши суть гастрономії і зіставивши iii $з$ сутністю туризму (як форми суспільного споживання), можна дійти висновку, що гастрономічний туризм - це виїзд особи із місця проживання для ознайомлення 3 традиціями, культурою, кращими практиками виготовлення та обслуговування продуктів харчування, що є невід'ємною частиною споживання високоякісних з унікальними смаковими властивостями харчових продуктів, страв і напоїв. Тобто, це подорож у визначене місце за межами місця проживання (до іншого населеного пункту, країни) підчас якої турист ставить за мету набуття досвіду та отримання нових знань про культуру, правила, форми і способи вироблення, обслуговування та поводження iз харчовими продуктами, стравами та напоями задля отримання їх високої якості та унікальних смаків, що може супроводжуватись куштуванням продуктів, напоїв та страв 3 унікальними смаковими властивостями.

Термін «атракція» у науковій літературі розуміється як видовище, розвага, що привертає увагу [12]. Тому зіставляючи зміст термінів атракція та гастрономічний туризм, під гастрономічною атракцією слід розуміти захід (видовище) метою якого є демонстрація, ознайомлення споживачів з традиціями, культурою, кращими практиками виготовлення, обслуговування, споживання високоякісних з унікальними смаковими властивостями харчових продуктів, страв i напоїв.

В Україні гастрономічні туристичні подорожі поступово входять у тренд. Базовою складовою будьякої гастрономічної атракції $є$ поєднання якісної харчової продукції, майстерності виробників, традицій і культури в їжі тієї місцевості, де розташована атракція. В основному гастротури включають одну чи декілька популярних гастрономічних атракцій серед яких виділяють: 1) різноманітні свята і фестивалі; 2) відвідання ресторанів, кав'ярень й інших закладів національної кухні; 3) відвідання селянських господарств, підприємств із виробництва харчової продукції, напоїв і т.п; 4) професійні заходи (тренінги, семінари, конкурси та інше).

Аналіз наукових праць та практики у сфері туризму показали, що гастрономічні атракції є доцільним класифікувати за видами в залежності від наступних ознак: 1) за місцем розташування - міські або сільські; 2) за часом функціонування - постійні, сезонні, разові; 3) за орієнтиром на потреби споживача - подієві (фестивалі, ярмарки, свята), гурманістичні (виключно для професіоналів справи - сомельє, поварів, м'ясників, садівників, тощо), культурнопізнавальні; 4) за спеціалізацією (в залежності від зосередження на основний харчовий продукт або напій) - сирні, м'ясні, рибні, фруктові, ягідні, овочеві, кавові, шоколадні, чайні, медові, олійно-жирові, делікатесні, винні, змішані та інші.

Орієнтація територіальних громад на розвиток екологічних видів туризму і залучення численних цільових груп споживачів до заняття туризмом на території приміської зони та у сільській місцевості зумовлює необхідність створення та розвитку унікальних туристичних атракцій, серед яких значне місце 
відводиться гастрономічним атракціям.

Садівництво традиційно в Україні є однією із форм забезпечення населення якісними, екологічно чистими продуктами харчування. Саме садівництво, як специфічна діяльність, що здійснюється відповідними суб'єктами землекористування, поєднує у собі культурну та соціально-економічну складові, робить значний внесок в охорону навколишнього природного середовища, розвиток культури, підвищення фінансової спроможності членів територіальних громад. Займаючись садівництвом громадяни одночасно займаються виробничою діяльністю, що приносить задоволення та розширює сферу пізнання, організовують дозвілля і відпочинок. Багато садівників $є$ хранителями традицій, взірцем зразкового відношення до природи та активними громадськими діячами, які розуміючи велику суспільну відповідальність все більше передають набуті досвід та знання широкому загалу споживачів, чим допомагають формувати культуру нації, стаючи при цьому об'єктом наслідування та у туристичному сенсі «атракцією», яка здатна викликати інтерес туристів відвідати місцевість де знаходиться такий садівник. Тому, поєднання культурного надбання місцевого побуту, особливостей оточуючого природного і техногенного середовища, результатів садівницької діяльності та майстерності місцевих жителів для кожної територіальної громади формують унікальний потенціал розвитку сектора гастрономічного туризму.

Однією з форм ведення садівницької діяльності $\epsilon$ садівницькі (садівничі) товариства, які $\epsilon$ об'єднанням фізичних осіб з метою здійснення колективного садівництва. Нині в Україні садівницькі товариства діють на підставі Закону України «Про кооперацію», Закону України «Про сільськогосподарську кооперацію» а також Закону України «Про громадські об'єднання», і згідно Класифікатора організаційно-правових форм господарювання є окремою організаційно-правовою формою. Разом 3 тим, на практиці реєстрація юридичних осіб за організаційноправовою формою у вигляді садівницького (садівничого) товариства не відбувається, а садівницькі товариства реєструються як кооперативи, або як громадські об'єднання.

Такі об'єднання мають у своєму складі власну територію, що складається із земельних ділянок членів товариства та земель загального користування, упорядкування та забудова якої здійснюється за генеральним планом. Садівничі товариства керуючись вимогами закону, установчого договору та статуту товариства визначають для членів товариства порядок використання земельних ділянок, порядок здійснення спільних заходів та розпорядження майном у тому числі із використанням спільних коштів. Саме тому садівницькі товариства представляють собою основу, що сприяє консолідації діяльності членів товариства задля досягнення спільної мети та цілей за визначеними напрямками діяльності.

Завдяки своєму правовому становищу садівницькі товариства отримали ряд конкурентних переваг, що робить їх привабливими організаційними та пра- вовими формами для заняття діяльністю яка дає змогу членам товариства самостійно та колективно створювати гастрономічні атракції, позиціонуючи території садівницького товариства, як територію туристичної дестинації.

Конкурентні переваги садівницького товариства проявляються за такими напрямкам: 1) у сфері бухгалтерського обліку - існує можливість вибору форми ведення обліку між простою, спрощеною або на загальних підставах; 2) у сфері фінансової звітності за загальним правилом подається у відповідні органи один раз на рік; 3) у сфері оподаткування та інших платежів - надаються пільги по сплаті земельного податку, сплаті платежів за користування деякими видами природних ресурсів; 4) у сфері житловокомунального обслуговування - члени садівницького товариства сплачують за комунальні послуги за тарифами для населення.

Виступаючи самостійним суб'єктом правовідносин, використовуючи інструменти менеджменту та маркетингу, існуючі садівницькі товариства здатні набути статусу об'єкта сфери туризму, сприяти формуванню на приватних земельних ділянках, що входять до складу об'єднання, взаємопов'язаних інфраструктурних елементів єдиної туристичної дестинації. Використовуючи території садівницьких товариств, як базу для організації гастрономічних атракцій і надання супутніх туристичних послуг, а також як основу формування комплексного туристичного продукту, садівницькі товариства сприятимуть створенню нових робочих місць, сприятимуть господарствам членів товариства розширити ринки збуту власно вирощеної садівничої продукції, сприятиме поліпшенню інфраструктури територій товариства та підвищенню фінансової спроможності членів та самого товариства. Окрім того, входячи до складу тієї чи іншої територіальної громади та співпрацюючи з органами місцевого самоврядування, садівницькі товариства стимулюють взаємовигідний розвиток: товариства здобувають можливість отримувати для себе та своїх членів на пільгових умовах державні дотації на розвиток туризму та садівничої діяльності, тим самим отримуючи змогу до широкого запровадження інноваційних технологій «зеленого» підприємництва, а територіальна громада - підвищення зайнятості місцевого населення, збільшення надходжень до місцевого бюджету, благоустрій території, відродження та розвиток притаманних територіям цієї громади промислів та культури, збереження та відновлення природного середовища, привернення уваги та підвищення інтересу до територіальної громади збоку садоводів та інших громадян, можливість економічного стимулювання ресурсозбереження у контексті сталого розвитку, та інше.

Висновки та перспективи подальших досліджень. Приймаючи до уваги вищевикладене можна дійти висновку, що об'єднання у формі садівницьких товариств мають потенціал, який дозволяє без значних початкових капіталовкладень сформувати соціально та економічно привабливу для споживачів та держави ланку: «виробництво екологічно 
чистого продовольства - туристична та рекреаційна діяльність - розбудова територіальних громад на засадах зеленої економіки за принципами сталого розвитку».

Гастрономічний туризм може стати для населення територіальних громад привабливим в якості виду господарської діяльності лише за умови відносно невеликих стартових інвестицій та швидкого отримання доходів, що у короткостроковій перспек- тиві дозволить використовувати отримані економічні вигоди з метою подальшого сталого розвитку територіальної громади.

Концептуальні засади, механізми та інструменти управління садівничими товариствами як гастрономічними туристичними дестинаціями становлять предмет і перспективи для подальших наукових досліджень в даному напрямку.

\section{Лiтература}

1. Стратегія розвитку туризму та курортів на період до 2026 року : Розпорядження Кабінету Міністрів України від 16.03.2017 p. №168-p. // База даних «Законодавство України»/BP України. URL: http://zakon.rada.gov.ua/laws/show/ru/168-2017-p (дата звернення 12.12.2018p.)

2. Туристична діяльність в Україні у 2017 році: Статистичний збірник // Державна служба статистики України. Київ: 2018. URL: http://www.ukrstat.gov.ua/druk/publicat/kat_u/2018/zb/05/zb_td_2017.pdf (дата 3вернення 17.12.2018p.)

3. Dasilva, D. Assessing The Economic Potential For Culinary Tourism In Suriname: A Value Chain Approach. // Caribbean Centre for Competitiveness. St. Augustine, Trinidad and Tobago, 2015. URL: http://www.surinamecompete.org/wp-content/uploads/2016/01/Assessing-The-Economic-Potential-Of-Culinary-

Tourism-Revised.pdf (дата звернення 17.12.2018p.)

4. Басюк Д. І. Інноваційний розвиток гастрономічного туризму в Україні. Наук. пр. НУХТ. 2012. №45. C. $128-132$.

5. Саламатіна С. С. Стан та перспективи розвитку гастрономічного туризму на півдні Одещини. Наук. пр. ОНАХТ. 2014. № 46. С. 325-329.

6. H. Ridvan Yurtseven. Sustainable Gastronomic Tourism in Gokceada (Imbros): Local and Authentic Perspectives. International Journal of Humanities and Social Science. 2011. Vol. 1 No. 18, pp. 17 - 26.

7. Офіційний сайт Світової асоціації харчового туризму. URL: http://www.worldfoodtravel.org. (дата звернення 17.12.2018p.)

8. Matilda Brokaj. The Impact of the Gastronomic Offer in Choosing Tourism Destination: The Case of Albania. Academic Journal of Interdisciplinary Studies MCSER Publishing. 2014. Vol. 3. No 2, pp. 249 - 258.

9. Тлумачний словник російської мови: у 4 т. / за ред. Д. М. Ушакова. Репринтне видання: М., 1995; М., 2000. 5527 c.

10. Словник іншомовних слів, які увійшли до складу російської мови./ Чудінов А. М., 1910 р. СПб. Видання книгопродавця В.І. Губинського, Друкарня С.Н. Худекова, 1894. - 1004 с.

11. Oxford English Dictionary. URL: http://www.oed.com. (дата звернення 16.12.2018p.)

12. Словопедія. URL: http://slovopedia.org.ua/101/53392/1060238.html (дата звернення 16.12.2018p.)

Стаття надійшла 15.01.2019 Стаття прийнята до друку 29.01.2019 Доступно в мережі Internet 19.03.2019

Лайко А.И.

доктор экономических наук, старший научный сотрудник

E-mail: alexlayko@gmail.com

ORCID ID: 0000-0001-7082-0862

Торган В.B.

аспирант

отдел межрегионального экономического развития Украинского Причерноморья

Институт проблем рынка и экономико-экологических исследований НАН Украины

Французский бульвар, 29, г.Одесса, Украина, 65044

E-mail: torganvv@gmail.com

ORCID ID: 0000-0002-8619-6117

\section{РОЛЬ САДОВОДЧЕСКИХ ОБЩЕСТВ В ОБЕСПЕЧЕНИИ РАЗВИТИЯ ГАСТРОНОМИЧЕСКИХ АТРАКЦИЙ И ФОРМИРОВАНИИ ТУРИСТИЧЕСКИХ ДЕСТИНАЦИЙ НА ОСНОВЕ ПРИНЦИПОВ ЗЕЛЕНОЙ ЭКОНОМИКИ}

Садоводство, как и любая другая работа на земле является не только приоритетным сектором экономики, но и увлекательным хобби, которое в сочетании с самобытной местной культурой и кухней 
способно создать уникальное туристическое предложение и привлечь внимание значительного числа внутренних и иностранных туристов.

В статье рассматриваются подходы и дается определение сущности понятий гастрономический туризм и гастрономическая аттракция, определяется классификация и обосновывается роль садоводческих обществ в развитии гастрономических аттракций, как инструмента развития гастрономического туризма в территориальных громадах Украины на основе зеленой экономики.

Целью статьи является определение теоретико-концептуальных основ по обоснованию развития гастрономических аттракций на базе садоводческих обществ в качестве основы для фоормирования туристических дестинаций в сельской и пригородной местности территориальных громад на основе зеленой экономики. Задачами исследования является проведение теоретико-семантического анализа сущности гастрономического туризма, обоснование сущности понятия гастрономическая аттракция и классификация видов гастрономических достопримечательностей, определение роли садоводческих товариществ как инструмента развития гастрономического туризма в территориальных общинах на основе зеленой экономики.

Применены методы системного, семантического анализа для определения сущности гастрономического туризма и гастрономических аттракций. Диалектические методы и теоретические обобщения использованы при формировании актуальных определений и терминов, классификации видов гастрономических аттракций и преимуществ садоводческих обществ в аспекте становления модели зеленой экономики. Методы институционального анализа применены при рассмотрении законодательных основ развития гастротуризма в садоводческих обществах в условиях децентрализации.

Обоснована роль садоводческих обществ, как инструмента развития гастрономических аттракций, инструмента формирования туристических дестинаций и обеспечения устойчивого развития территориальных громад на основе зеленой экономики.

Установлено, что садоводческие общества как основа гастрономических аттракций так же являются основой формирования туристических дестинаций в территориальных громадах, и в дальнейшем будут способствовать стимулированию роста экономической активности, усилению процессов рурбанизации, а так же обеспечивать устойчивое развитие туризма в территориальных громадах на основе зеленой экономики. Концептуальные основы, механизмы и инструменты управления садовыми товариществами в качестве гастрономических аттракций и туристических дестинаций составляют предмет и перспективы для дальнейших научных исследований в данном направлении.

Ключевые слова: гастрономия, гастрономический туризм, садоводческие (садовые) общества, гастрономическая аттракция, туристические дестинации, устойчивое развитие территориальных громад, зеленая экономика.

Laiko 0.

Doctor of Economics, Senior Researcher

E-mail: alexlayko@gmail.com

ORCID ID: 0000-0001-7082-0862

Torgan V.

Postgraduate Student

Department of Interregional Economic Development of the Ukrainian Black Sea Region Institute of Market Problems and Economic \& Ecological Research

of National Academy of Sciences of Ukraine

Frantsuzskiy boulevard, 29, Odesa, Ukraine, 65044

E-mail: torganvv@gmail.com

ORCID ID: 0000-0002-8619-6117

\section{THE ROLE OF HORTICULTURAL SOCIETIES IN PROVIDING DEVELOPMENT OF GASTRONOMIC ATTRACTS AND FORMING TOURIST DESTINATIONS ON THE BASIS OF THE GREEN ECONOMY}

Gardening, like any other work on earth, is not only a priority sector of the economy, but also an exciting hobby that, combined with original local culture and cuisine, can create a unique tourist destination and attract the attention of a large number of domestic and foreign tourists.

The article deals with approaches and defines the essence of the concepts of gastronomic tourism and gastronomic attraction, defines the classification of gastronomic attractions, the role of gardening societies in developing gastronomic attractions as a tool for the development of gastronomic tourism in the territorial communities of Ukraine on the principles of the green economy. 
The purpose of the article is to determine the theoretical and conceptual foundations for the development of gastronomic attractions on the basis of horticultural societies as the basis for the formation of tourist destinations in rural and suburban areas of the territorial communities on the principles of the green economy. The objectives of the study are to conduct theoretical and semantic analysis of the essence of gastronomic tourism, to substantiate the essence of the concept of gastronomic attraction and the classification of types of gastronomic attractions, the definition of the role of gardening societies as a tool for the development of gastronomic tourism in the territorial communities on the principles of the green economy.

Methods of systematic and semantic analysis are used to determine the essence of gastronomic tourism and gastronomic attractions. Dialectical methods and theoretical generalizations are used during the formation of actual definitions and terms, the classification of types of gastronomic attractions and the benefits of horticultural societies in the aspect of the formation of a green economy model. Methods of institutional analysis are used when considering the legislative framework for the development of gastro tourism in gardening societies in the context of decentralization.

The role of gardening societies as an instrument of development of gastronomic attractions, formation of tourist destinations and ensuring the sustainable development of territorial communities on the basis of the green economy is substantiated.

Gardening societies as the basis of gastronomic attractions are the basis for the formation of tourist destinations in the territorial communities, and will further promote the growth of economic activity, strengthen the processes of rurbanization and ensure the sustainable development of tourism in the territorial communities on the principles of the green economy. Conceptual foundations, mechanisms and tools of gardening societies management as gastronomic attractions and tourist destinations are the subject and prospects for further research in this direction.

Key words: gastronomy, gastronomic tourism, gardening societies, gastronomic attractions, tourist destinations, sustainable development of territorial communities, green economy.

\section{References}

1. Stratehiia rozvytku turyzmu ta kurortiv na period do 2026 roku. (2017). Retrieved December 12, 2018, from http://zakon.rada.gov.ua/laws/show/ru/168-2017-p

2. Turystychna diialnist v Ukraini u 2017 rotsi. (2018). Retrieved December 17, 2018, from http://www.ukrstat.gov.ua/druk/publicat/kat_u/2018/zb/05/zb_td_2017.pdf

3. Dasilva, D. (2015). Assessing The Economic Potential For Culinary Tourism In Suriname: A Value Chain Approach. Retrieved December 17, 2018, from http://www.surinamecompete.org/wpcontent/uploads/2016/01/Assessing-The-Economic-Potential-Of-Culinary-Tourism-Revised.pdf

4. Basiuk, D. I. (2012). Innovatsiinyi rozvytok hastronomichnoho turyzmu v Ukraini. Naukovi Pratsi NUKhT, (45), 128-132.

5. Salamatina, S. Ye. (2014). Stan ta perspektyvy rozvytku hastronomichnoho turyzmu na pivdni Odeshchyny. Naukovi Pratsi ONAKhT, (46), 325-329.

6. Ridvan Yurtseven, H. (2011). Sustainable Gastronomic Tourism in Gokceada (Imbros): Local and Authentic Perspectives. International Journal of Humanities and Social Science, 1(18), 17-26.

7. Ofitsiinyi sait Svitovoi asotsiatsii kharchovoho turyzmu. (2018). Retrieved December 17, 2018, from http://www.worldfoodtravel.org.

8. Brokaj, M. (2014). The Impact of the Gastronomic Offer in Choosing Tourism Destination: The Case of Albania. Academic Journal of Interdisciplinary Studies MCSER Publishing, 3(2), 249-258.

9. Ushakov, D. M. (Ed.). (2000). Tlumachnyi slovnyk rosiiskoi movy (Repryntne ed.). Moscow.

10. Chudinov, A. M. (1894). Slovnyk inshomovnykh sliv, yaki uviishly do skladu rosiiskoi movy. SPb.: Vydannia knyhoprodavtsia V.I. Hubynskoho.

11. Oxford English Dictionary. (2018). Retrieved December 16, 2018, from http://www.oed.com.

12. Slovopediia. Retrieved December 16, 2018, from http://slovopedia.org.ua/101/53392/1060238.html

Received 15 January 2019

Approved 29 January 2019

Available in Internet 19.03.2019

Цитування згідно ДСТУ 8302:2015

Лайко О.І., Торган В.В. Роль садівницьких товариств в забезпеченні розвитку гастрономічних атракцій і формуванні туристичних дестинацій на засадах зеленої економіки // Економіка харчової промисловості. 2019. Т.11, вип. 1. С. 3-9; doi: 10.15673/fie.v11i1.1289

Cite as APA style citation

Laiko O., \& Torgan V. (2019). The role of horticultural societies in providing development of gastronomic attracts and forming tourist destinations on the basis of the green economy. Food Industry Economics, 11(1), 3-9; doi: 10.15673/fie.v11i1.1289 